\title{
Hubungan Media Massa online dengan Pemenuhan Kebutuhan Informasi Mahasiswa
}

\author{
Mohammad Rezandy Akbar* \\ Fakultas Ilmu Komunikasi, Universitas Islam Bandung, Indonesia. \\ *rezandyakbar1@gmail.com
}

\begin{abstract}
At this time, the mass communication media that is growing very rapidly is the online mass media (online newspapers). The existence of online mass media is not limited by time and space, so that users can use it wherever and whenever they want. In 2020, the world was shocked by a virus that originated in China or more precisely in Wuhan, namely the Corona or Covid-19 virus. All media are reporting about Covid-19, including Tempo.co. The method used by researchers is quantitative research methods with a correlational study approach. Researchers use the uses and gratifications theory from Blumler in Jalauddin Rakhmat's book and one of the news values is novelty, actual, and information. Blumler said there are 3 motive orientations, namely cognitive orientation, diversion, and personal identity. The population in this study were 207 students of Journalism at the Faculty of Communication Sciences Unisba. So by determining the sample using the Slovin formula obtained 67 respondents. The results showed that: (1) the indicator of the novelty value of the COVID-19 prevention news on Tempo.co has an effect on cognitive needs, diversion, and personal identity (2) the actual indicators of the news on the prevention of covid-19 on Tempo.co have an effect on cognitive needs, diversion and personal identity (3) indicators of news information on the response to covid-19 on Tempo.co have an effect on cognitive needs, diversion, and personal identity.
\end{abstract}

Keywords: Online Mass Media, Covid-19, News, Fulfillment of Information Needs

\begin{abstract}
Abstrak. Pada saat ini, media komunikasi massa yang berkembang sangat pesat adalah media massa online (surat kabar online). Keberadaan media massa online tidak terbatas ruang dan waktu sehingga penggunanya dapat menggunakan di manapun dan kapanpun yang mereka kehendaki. Pada tahun 2020 ini, dunia dikejutkan oleh suatu virus yang asal mulanya dari Cina atau lebih tepatnya di Wuhan, yaitu virus Corona atau Covid-19. Seluruh media memberitakan tentang Covid-19 ini, termasuk Tempo.co. Metode yang digunakan peneliti yaitu metode penelitian kuantitatif dengan pendekatan studi korelasional. Peneliti menggunakan teori uses and gratifications dari Blumler dalam buku Jalauddin Rakhmat dan salah satu nilai berita yaitu kebaharuan, aktual, dan informasi. Blumler menyebutkan ada 3 orientasi motif yaitu orientasi kognitif, diversi, dan identitas personal. Populasi dalam penelitian ini adalah mahasiswa Jurnalistik Fikom Unisba yang berjumlah 207 orang. Maka dengan penentuan sampel menggunakan rumus slovin didapat 67 responden. Hasil penelitian menunjukkan bahwa: (1) pada indikator nilai kebaharuan berita penanggulangan covid-19 di Tempo.co berpengaruh pada kebutuhan kognitif, diversi, dan identitas personal (2) indikator aktual berita penanggulangan covid-19 di Tempo.co berpengaruh pada kebutuhan kognitif, diversi, dan identitas personal (3) indikator informasi berita penanggulangan covid-19 di Tempo.co berpengaruh pada kebutuhan kognitif, diversi, dan identitas personal.
\end{abstract}

Kata kunci: Media Massa Online, Covid-19, Berita, Pemenuhan Kebutuhan Informasi 


\section{A. Pendahuluan}

Pada saat ini, media komunikasi massa yang berkembang sangat pesat adalah media massa online (surat kabar online). Dengan media massa online, informasi dari belahan dunia manapun dapat diperoleh. Kecepatannya yang tinggi dalam memberikan informasi, membuat media massa online banyak digunakan oleh masyarakat pada saat ini. Keberadaan media massa online tidak terbatas ruang dan waktu sehingga penggunanya dapat menggunakan dimanapun dan kapanpun yang mereka kehendaki. Sebagai media massa, media massa online juga menggunakan kaidah-kaidah jurnalistik dalam sistem kerja mereka. Pada saat ini, media massa online menjadi alternatif lain untuk memenuhi kebutuhan informasi khalayaknya.

Pada tahun 2020 ini, dunia dikejutkan oleh suatu virus yang asal mulanya dari Wuhan, yaitu virus Corona atau Covid-19. Ditemukan pada akhir Desember tahun 2019. Dilansir dari Kompas.com, WHO (World Health Organization) sejak bulan Januari 2020 telah menyatakan bahwa wabah virus corona ini sebagai darurat kesehatan global atau Public Health Emergency of International Concern (PHEIC). Virus ini sudah menyebar ke beberapa negara, salah satunya Indonesia. Virus ini sangat mengkhawatirkan masyarakat karena penyebarannya yang cepat dan mematikan.

Salah satu pemberitaan yang sering menjadi sorotan pada saat ini adalah masalah virus covid-19 di Indonesia. Pemberitaan terkait virus corona telah meningkatkan kesadaran masyarakat dalam mencegah dan menanggulangi bahaya virus dan banjirnya informasi terkait virus corona juga membuat publik menjadi labirin informasi. Kasus mengenai penyebaran virus corona tersebar luas dan disebarkan melalui internet (web atau blog) dan media sosial (Supriadi, dkk. 2020). Banyak media di seluruh dunia memberitakan tentang covid-19 ini, Tempo.co salah satunya yang rutin memberitakan isu virus covid-19. Pada bulan September 2020, Indonesia mengalami lonjakan kasus yang terkonfirmasi positif covid-19 menurut Komite Penanganan Covid-19 dan Pemulihan Ekonomi Nasional. Peningkatan kasus terjadi hingga dua kali lipat dibanding dengan bulan sebelumnya. Tercatat pada tanggal 25 September 2020 kasus covid-19 di Indonesia mencapai 4.823 kasus. Maka dari itu peneliti memilih lima berita terkait dengan penanggulangan covid-19 di tanggal 25 September 2020 pada saat puncak kenaikan kasus covid-19 di Indonesia. Ada pun berita-berita yang peneliti pilih yaitu berjudul "Jokowi: Sejak Awal, Pemerintah Konsisten Bahwa Kesehatan Prioritas Utama", "Kasus Positif Covid-19 Terus Bertambah, Luhut: Penanganan Berjalan Terkendali", "PSBB Ketat Diperpanjang, Anies Baswedan: Kasus Aktif Covid-19 Masih Rentan", "Update: Pasien Covid-19 yang Sembuh di RS Darurat Wisma Atlet Capai 15.126", dan "Kabupaten Bekasi Terjunkan Pemburu Pelanggar Protokol Kesehatan, Ini Taktiknya". Peneliti memilih 5 berita tersebut karena mewakili dengan informasi mengenai penanganan covid-19.

Khalayak media massa online biasanya adalah orang yang melek akan teknologi karena dalam pengoperasiannya media massa online menggunakan perangkat komputer dan jaringan internet. Dengan menggunakan media massa online, perhatian khalayak tertuju pada berita apa yang akan dicari, tidak seorangpun dapat mengendalikan perhatian khalayak. Khalayak juga bisa keluar masuk sesuai dengan apa yang ingin dibaca. Mahasiswa adalah salah satu pembaca media massa online karena sangat mudah diakses melalui smartphone yang kebanyakan telah dimiliki oleh mahasiswa.

Pada penelitian ini, peneliti tertarik untuk meneliti mengenai pemenuhan kebutuhan informasi. Peneliti menilai bahwa mahasiswa sebagai khalayak yang membaca informasi covid19 pada pemberitaan di Tempo.co informasi yang mereka butuhkan terpenuhi atau tidak. Peneliti memilih subjek khalayaknya adalah mahasiswa jurnalistik Fikom Unisba karena mereka mempelajari ilmu-ilmu tentang kejurnalistikan.

Untuk melakukan penelitian ini, peneliti menggunakan salah satu dari nilai berita dan teori uses and gratifications dari Blumler dalam buku Jalauddin Rakhmat. Blumler menyebutkan ada 3 orientasi motif yaitu orientasi kognitif (kebutuhan akan informasi, surveillance, atau eksplorasi realitas), diversi (kebutuhan akan pelepasan dari tekanan dan kebutuhan akan hiburan), serta identitas personal (yakni menggunakan isi media untuk memperkuat/menonjolkan sesuatu yang penting dalam kehidupan atau situasi khalayak sendiri). 


\section{B. Metodologi}

Penelitian ini menggunakan penelitian kuantitatif yang bertujuan menguji hipotesa dari datadata yang telah dikumpulkan sesuai dengan teori dan konsep sebelumnya. Penelitian kuantitatif adalah suatu penelitian yang dilakukan dengan menggunakan pendekatan deduktif induktif yang berangkat dari suatu kerangka teori, gagasan para ahli, ataupun pemahaman peneliti berdasarkan pengalamannya yang kemudian dikembangkan menjadi permasalahan-permasalahan beserta pemecahan-pemecahannya yang diajukan untuk memperoleh pembenaran dalam bentuk dukungan data di lapangan. Penelitian ini termasuk dalam jenis metode penelitian korelasional. Dikutip dari jurnal tentang penelitian korelasi disebutkan penelitian korelasi atau korelasional adalah suatu penelitian untuk mengetahui hubungan dan pengaruh antara dua variabel atau lebih tanpa ada upaya untuk mempengaruhi variabel tersebut sehingga tidak terdapat manipulasi variabel (Faenkel dan Wallen, 2008:328). Penelitian ini menggunakan pendekatan korelasional yang betujuan untuk meneliti hubungan antara variabel-variabel.

Berita adalah laporan tercepat mengenai fakta atau ide terbaru yang benar, menarik atau penting bagi sebagian besar khalayak, melalui media berkala seperti surat kabar, radio, televisi, atau media online. Menurut AS Haris Sumadiria, nilai berita atau news adalah laporan tentang suatu peristiwa, opini, kecenderungan, situasi, kondisi, interpretasi yang penting, menarik dan masih baru. Harus secepatnya di sampaikan. Secara ringkas berita dapat dikatakan yaitu jalan cerita tentang peristiwa. Ini berarti bahwa suatu berita setidaknya mengandung dua hal, yaitu peristiwa dan jalan ceritanya.

Media massa online merupakan tipe baru jurnalisme karena memiliki sejumlah fitur dan karakteristik dari jurnalisme tradisional. Fitur-fitur uniknya mengemuka dalam teknologinya, menawarkan kemungkinan-kemungkinan tidak terbatas dalam memproses dan menyebarkan berita (Septiawan Santana K, 2005:137). Dalam fungsi yang ada, fungsi utama media online adalah fungsi Surveillance, yaitu memberikan informasi kepada khalayaknya. Tetapi bukan itu saja, media online juga mencakup semua fungsi komunikasi massa yang lain.

Ada sebelas nilai berita menurut Brians S. Brooks, George Kennedy, Darly R. Moen, dan Don Ranly dalam News Reporting and Editing (1980:6-17) yaitu: (1) keluarbiasaan (unusualness); (2) kebaharuan (newness); (3) akibat (impact); (4) aktual (timeliness); (5) kedekatan (proximity); (6) informasi (information); (7) konflik (conflict); (8) orang penting (prominence); (9) ketertarikan manusia (human interest); (10) kejutan (surprising); dan (11) seks (sex). Peneliti memilih salah satu nilai berita yang dianggap berhubungan dengan berita penanggulangan covid-19, yaitu kebaharuan, aktual, dan informasi.

Teori uses and gratifications memusatkan perhatian pada penggunaan (uses) media untuk mendapatkan kepuasan (gratifications) atas kebutuhan seseorang. Penilaian tentang arti kultural dari media massa harus ditangguhkan sebelum diteliti lebih dahulu orientasi khalayak. (Elvinaro Ardianto, 2007:71). Seseorang menggunakan media massa didorong oleh motif-motif tertentu. Motif-motif itulah yang mendorong seseorang untuk menggunakan media massa yang mereka inginkan. Kebutuhan kognitif inilah yang menyebabkan seseorang memilih media untuk memenuhi kebutuhan informasinya. Motif dapat dioperasionalkan dalam berbagai cara, Blummer dalam Jalaluddin Rahmat (1993: 66) menyebutkan tiga orientasi, yaitu:

1. Kognitif, yaitu kebutuhan akan informasi, surveillance, atau eksplorasi realitas.

2. Diversi, yaitu kebutuhan akan pelepasan dari tekanan dan kebutuhan akan hiburan.

3. Identitas Personal, yaitu menggunakan isi media untuk memperkuat atau menonjolakan sesuatu yang penting dalam kehidupan atau situasi khalayak itu sendiri.

\section{Hasil dan Pembahasan}

Untuk mengetahui hubungan antara pemberitaan penanggulangan covid-19 di Tempo.co dengan pemenuhan kebutuhan informasi pada mahasiswa Jurnalistik Fikom Unisba, maka dilakukan analisa data dengan analisis korelasi rank Spearman yang dilanjutkan dengan uji hipotesis. Analisis korelasional dilakukan antara sub variable independen (kebaharuan, actual, informasi) dengan variable dependen (kebutuhan kognitif, kebutuhan diversi, kebutuhan identitas personal), dan di bagian akhir dilakukan analisis korelasi antara variable independen 
(pemberitaan penanggulangan covid-19 di Tempo.co) dan variable dependen (pemenuhan kebutuhan informasi) sebagai kesimpulan umum. Berikut hasil analisis:

\section{Hubungan Antara Kebaharuan dengan Kebutuhan Kognitif}

Tabel 1. Hasil Analisis Hubungan Kebaharuan dengan

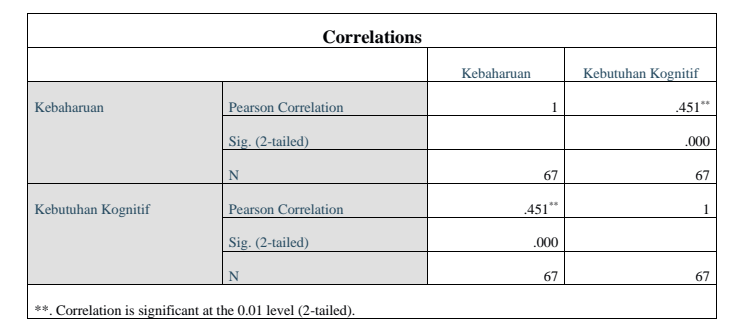

Berdasarkan uji korelasi yang telah dilakukan, diputuskan hasil bahwa kedua dimensi yang diujikan terdapat hubungan yang signifikan dengan nilai sig. (2-tailed) $<$ dari nilai $\alpha$, yaitu $(0.00<0.01)$ artinya $\mathrm{H} 0$ ditolak dan $\mathrm{H} 1$ yang berbunyi "Terdapat hubungan antara kebaharuan pemberitaan penanggulangan covid-19 di Tempo.co dengan kebutuhan kognitif pada mahasiswa Jurnalistik Fikom Unisba" diterima. Koefisien korelasi pun menunjukkan angka 0,451 yang berarti terdapat hubungan yang cukup berarti antara variabel $\left(X_{1}\right)$ indicator kebaharuan dengan variabel $\left(\mathrm{Y}_{1}\right)$ kebutuhan kognitif. Nilai koefisien korelasi yang positif atau searah menandakan bahwa semakin besar aspek kebaharuan pada pemberitaan penanggulangan covid-19 di Tempo.co semakin ditingkatkan akan berdampak baik pada kebutuhan kognitif pada mahasiswa Jurnalistik Fikom Unisba.

Sesuai dengan hasil kuisioner online yang peneliti sebarkan, dan dari hasil uji statistik SPSS versi 25, peneliti mendapatkan hasil yang sesuai dengan apa yang sedang diteliti. Bahwa ada hubungan antara $X_{1}$ dan $Y_{1}$ yaitu, Kebaharuan berita dengan kebutuhan kognitif. Sesuai dengan teori yang sudah dijabarkan oleh peneliti pada bab sebelumnya. Yang mana Kebaharuan berita dapat mempengaruhi atau ada hubungannya dengan kebutuhan kognitif pada mahasiswa Jurnalistik Fikom Unisba.

\section{Hubungan Antara Kebaharuan dengan Kebutuhan Diversi}

Tabel 2. Hasil Analisis Hubungan Kebaharuan dengan

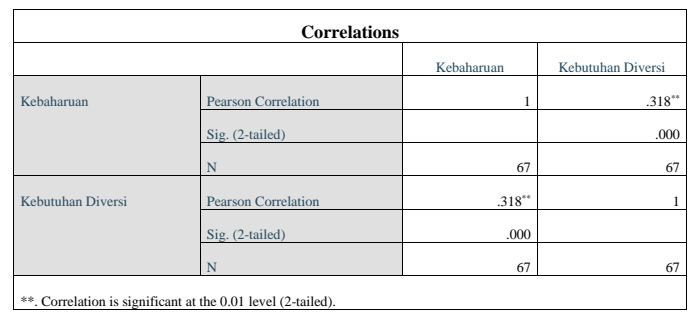

Berdasarkan uji korelasi yang telah dilakukan, diputuskan hasil bahwa kedua dimensi yang diujikan terdapat hubungan yang signifikan dengan nilai sig. (2-tailed) $<$ dari nilai $\alpha$, yaitu $(0.00<0.01)$ artinya $\mathrm{H} 0$ ditolak dan $\mathrm{H} 1$ yang berbunyi "Terdapat hubungan antara kebaharuan pemberitaan penanggulangan covid-19 di Tempo.co dengan kebutuhan diversi pada mahasiswa Jurnalistik Fikom Unisba" diterima. Koefisien korelasi pun menunjukkan angka 0,318 yang berarti terdapat hubungan rendah tetapi pasti antara variabel $\left(\mathrm{X}_{1}\right)$ indikator kebaharuan dengan variabel $\left(\mathrm{Y}_{2}\right)$ kebutuhan diversi. Nilai koefisien korelasi yang positif atau searah menandakan bahwa semakin besar aspek kebaharuan pada pemberitaan penanggulangan covid-19 di Tempo.co semakin ditingkatkan akan berdampak baik pada kebutuhan diversi pada mahasiswa Jurnalistik Fikom Unisba 
Sesuai dengan hasil kuisioner online yang peneliti sebarkan, dan dari hasil uji statistik SPSS versi 25 , peneliti mendapatkan hasil yang sesuai dengan apa yang sedang diteliti. Bahwa ada hubungan antara $\mathrm{X}_{1}$ dan $\mathrm{Y}_{2}$ yaitu, Kebaharuan berita dengan kebutuhan diversi. Sesuai dengan teori yang sudah dijabarkan oleh peneliti pada bab sebelumnya. Yang mana Kebaharuan berita dapat mempengaruhi atau ada hubungannya dengan kebutuhan diversi pada mahasiswa Jurnalistik Fikom Unisba.

\section{Hubungan Antara Kebaharuan dengan Kebutuhan Identitas Personal}

Tabel 3. Hasil Analisis Hubungan Kebaharuan dengan

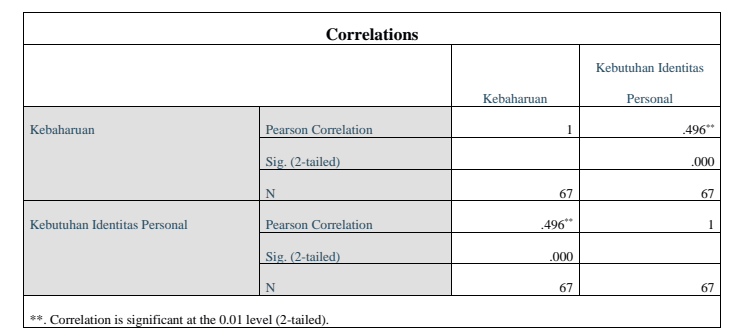

Berdasarkan uji korelasi yang telah dilakukan, diputuskan hasil bahwa kedua dimensi yang diujikan terdapat hubungan yang signifikan dengan nilai sig. (2-tailed) $<$ dari nilai $\alpha$, yaitu $(0.00<0.01)$ artinya H0 ditolak dan H1 yang berbunyi "Terdapat hubungan antara kebaharuan pemberitaan penanggulangan covid-19 di Tempo.co dengan kebutuhan identitas personal pada mahasiswa Jurnalistik Fikom Unisba" diterima. Koefisien korelasi pun menunjukkan angka 0,496 yang berarti terdapat hubungan yang cukup berarti antara variabel $\left(\mathrm{X}_{1}\right)$ indikator kebaharuan dengan variabel $\left(\mathrm{Y}_{3}\right)$ kebutuhan identitas personal. Nilai koefisien korelasi yang positif atau searah menandakan bahwa semakin besar aspek kebaharuan pada pemberitaan penanggulangan covid-19 di Tempo.co semakin ditingkatkan akan berdampak baik pada kebutuhan identitas personal pada mahasiswa Jurnalistik Fikom Unisba

Sesuai dengan hasil kuisioner online yang peneliti sebarkan, dan dari hasil uji statistik SPSS versi 25, peneliti mendapatkan hasil yang sesuai dengan apa yang sedang diteliti. Bahwa ada hubungan antara $\mathrm{X}_{1}$ dan $\mathrm{Y}_{3}$ yaitu, Kebaharuan berita dengan kebutuhan identitas personal. Sesuai dengan teori yang sudah dijabarkan oleh peneliti pada bab sebelumnya. Yang mana Kebaharuan berita dapat mempengaruhi atau ada hubungannya dengan kebutuhan identitas personal pada mahasiswa Jurnalistik Fikom Unisba.

\section{Hubungan Antara Aktual dengan Kebutuhan Kognitif}

Tabel 4. Hasil Analisis Hubungan Aktual dengan

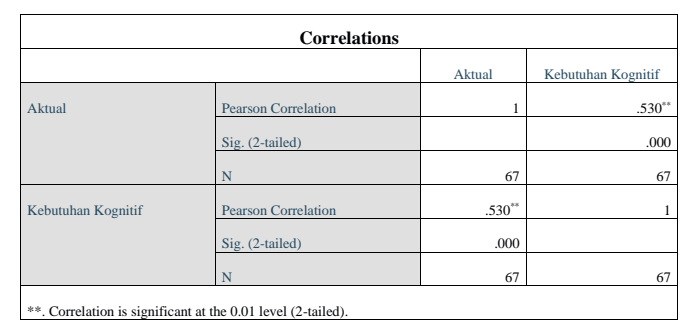

Berdasarkan uji korelasi yang telah dilakukan, diputuskan hasil bahwa kedua dimensi yang diujikan terdapat hubungan yang signifikan dengan nilai sig. (2-tailed) $<$ dari nilai $\alpha$, yaitu $(0.00<0.01)$ artinya $\mathrm{H} 0$ ditolak dan $\mathrm{H} 1$ yang berbunyi "Terdapat hubungan antara aktual pemberitaan penanggulangan covid-19 di Tempo.co dengan kebutuhan kognitif pada mahasiswa Jurnalistik Fikom Unisba" diterima. Koefisien korelasi pun menunjukkan angka 0,530 yang berarti terdapat hubungan yang cukup berarti antara variabel $\left(\mathrm{X}_{2}\right)$ indicator aktual 
dengan variabel $\left(\mathrm{Y}_{1}\right)$ kebutuhan kognitif. Nilai koefisien korelasi yang positif atau searah menandakan bahwa semakin besar aspek aktual pada pemberitaan penanggulangan covid-19 di Tempo.co semakin ditingkatkan akan berdampak baik pada kebutuhan kognitif pada mahasiswa Jurnalistik Fikom Unisba.

Sesuai dengan hasil kuisioner online yang peneliti sebarkan, dan dari hasil uji statistik SPSS versi 25 , peneliti mendapatkan hasil yang sesuai dengan apa yang sedang diteliti. Bahwa ada hubungan antara $X_{2}$ dan $Y_{1}$ yaitu, aktual berita dengan kebutuhan kognitif. Sesuai dengan teori yang sudah dijabarkan oleh peneliti pada bab sebelumnya. Yang mana aktual berita dapat mempengaruhi atau ada hubungannya dengan kebutuhan kognitif pada mahasiswa Jurnalistik Fikom Unisba.

\section{Hubungan Antara Aktual dengan Kebutuhan Diversi}

Tabel 5. Hasil Analisis Hubungan Aktual dengan

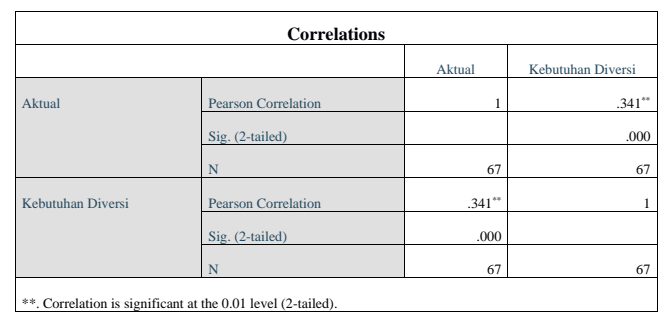

Berdasarkan uji korelasi yang telah dilakukan, diputuskan hasil bahwa kedua dimensi yang diujikan terdapat hubungan yang signifikan dengan nilai sig. (2-tailed) $<$ dari nilai $\alpha$, yaitu $(0.00<0.01)$ artinya H0 ditolak dan H1 yang berbunyi "Terdapat hubungan antara aktual pemberitaan penanggulangan covid-19 di Tempo.co dengan kebutuhan diversi pada mahasiswa Jurnalistik Fikom Unisba" diterima. Koefisien korelasi pun menunjukkan angka 0,341 yang berarti terdapat hubungan rendah tetapi pasti antara variabel $\left(\mathrm{X}_{2}\right)$ indikator aktual dengan variabel $\left(\mathrm{Y}_{2}\right)$ kebutuhan diversi. Nilai koefisien korelasi yang positif atau searah menandakan bahwa semakin besar aspek aktual pada pemberitaan penanggulangan covid-19 di Tempo.co semakin ditingkatkan akan berdampak baik pada kebutuhan diversi pada mahasiswa Jurnalistik Fikom Unisba.

Sesuai dengan hasil kuisioner online yang peneliti sebarkan, dan dari hasil uji statistik SPSS versi 25 , peneliti mendapatkan hasil yang sesuai dengan apa yang sedang diteliti. Bahwa ada hubungan antara $X_{2}$ dan $Y_{2}$ yaitu, aktual berita dengan kebutuhan diversi. Sesuai dengan teori yang sudah dijabarkan oleh peneliti pada bab sebelumnya. Yang mana aktual berita dapat mempengaruhi atau ada hubungannya dengan kebutuhan diversi pada mahasiswa Jurnalistik Fikom Unisba.

\section{Hubungan Antara Aktual dengan Kebutuhan Identitas Personal}

Tabel 6. Hasil Analisis Hubungan Aktual dengan

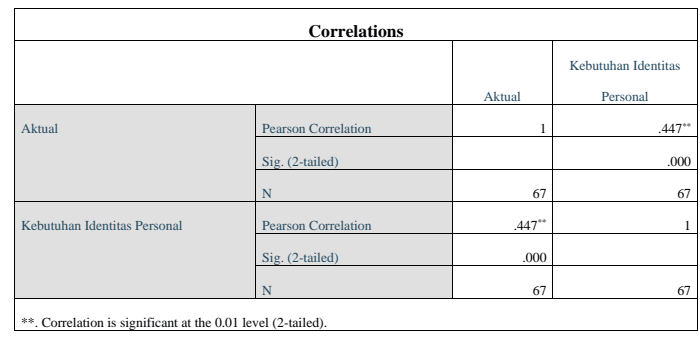

Berdasarkan uji korelasi yang telah dilakukan, diputuskan hasil bahwa kedua dimensi yang diujikan terdapat hubungan yang signifikan dengan nilai sig. (2-tailed) $<$ dari nilai $\alpha$, yaitu 
$(0.00<0.01)$ artinya H0 ditolak dan H1 yang berbunyi "Terdapat hubungan antara aktual pemberitaan penanggulangan covid-19 di Tempo.co dengan kebutuhan identitas personal pada mahasiswa Jurnalistik Fikom Unisba" diterima. Koefisien korelasi pun menunjukkan angka 0,447 yang berarti terdapat hubungan yang cukup berarti antara variabel $\left(\mathrm{X}_{2}\right)$ indikator aktual dengan variabel $\left(\mathrm{Y}_{3}\right)$ kebutuhan identitas personal. Nilai koefisien korelasi yang positif atau searah menandakan bahwa semakin besar aspek aktual pada pemberitaan penanggulangan covid-19 di Tempo.co semakin ditingkatkan akan berdampak baik pada kebutuhan identitas personal pada mahasiswa Jurnalistik Fikom Unisba.

Sesuai dengan hasil kuisioner online yang peneliti sebarkan, dan dari hasil uji statistik SPSS versi 25 , peneliti mendapatkan hasil yang sesuai dengan apa yang sedang diteliti. Bahwa ada hubungan antara $X_{2}$ dan $Y_{3}$ yaitu, aktual berita dengan kebutuhan identitas personal. Sesuai dengan teori yang sudah dijabarkan oleh peneliti pada bab sebelumnya. Yang mana aktual berita dapat mempengaruhi atau ada hubungannya dengan kebutuhan identitas personal pada mahasiswa Jurnalistik Fikom Unisba.

\section{Hubungan Antara Informasi dengan Kebutuhan Kognitif}

Tabel 7. Hasil Analisis Hubungan Informasi dengan

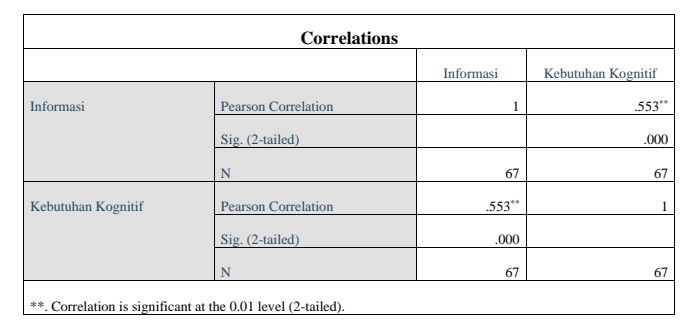

Berdasarkan uji korelasi yang telah dilakukan, diputuskan hasil bahwa kedua dimensi yang diujikan terdapat hubungan yang signifikan dengan nilai sig. (2-tailed) $<$ dari nilai $\alpha$, yaitu $(0.00<0.01)$ artinya H0 ditolak dan H1 yang berbunyi "Terdapat hubungan antara informasi pemberitaan penanggulangan covid-19 di Tempo.co dengan kebutuhan kognitif pada mahasiswa Jurnalistik Fikom Unisba" diterima. Koefisien korelasi pun menunjukkan angka 0,553 yang berarti terdapat hubungan yang cukup berarti antara variabel $\left(\mathrm{X}_{3}\right)$ indikator informasi dengan variabel $\left(\mathrm{Y}_{1}\right)$ kebutuhan kognitif. Nilai koefisien korelasi yang positif atau searah menandakan bahwa semakin besar aspek informasi pada pemberitaan penanggulangan covid-19 di Tempo.co semakin ditingkatkan akan berdampak baik pada kebutuhan kognitif pada mahasiswa Jurnalistik Fikom Unisba.

Sesuai dengan hasil kuisioner online yang peneliti sebarkan, dan dari hasil uji statistik SPSS versi 25 , peneliti mendapatkan hasil yang sesuai dengan apa yang sedang diteliti. Bahwa ada hubungan antara $\mathrm{X}_{3}$ dan $\mathrm{Y}_{1}$ yaitu, informasi berita dengan kebutuhan kognitif. Sesuai dengan teori yang sudah dijabarkan oleh peneliti pada bab sebelumnya. Yang mana informasi berita dapat mempengaruhi atau ada hubungannya dengan kebutuhan kognitif pada mahasiswa Jurnalistik Fikom Unisba.

\section{Hubungan Antara Informasi dengan Kebutuhan Diversi}

Tabel 8. Hasil Analisis Hubungan Informasi dengan

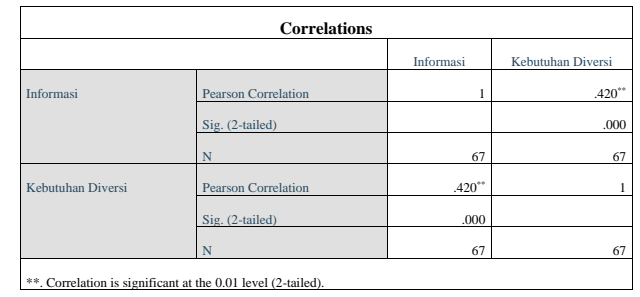


Berdasarkan uji korelasi yang telah dilakukan, diputuskan hasil bahwa kedua dimensi yang diujikan terdapat hubungan yang signifikan dengan nilai sig. (2-tailed) $<$ dari nilai $\alpha$, yaitu $(0.00<0.01)$ artinya $\mathrm{H} 0$ ditolak dan $\mathrm{H} 1$ yang berbunyi "Terdapat hubungan antara informasi pemberitaan penanggulangan covid-19 di Tempo.co dengan kebutuhan diversi pada mahasiswa Jurnalistik Fikom Unisba" diterima. Koefisien korelasi pun menunjukkan angka 0,420 yang berarti terdapat hubungan yang cukup berarti antara variabel $\left(\mathrm{X}_{3}\right)$ indikator informasi dengan variabel $\left(\mathrm{Y}_{2}\right)$ kebutuhan diversi. Nilai koefisien korelasi yang positif atau searah menandakan bahwa semakin besar aspek informasi pada pemberitaan penanggulangan covid-19 di Tempo.co semakin ditingkatkan akan berdampak baik pada kebutuhan diversi pada mahasiswa Jurnalistik Fikom Unisba.

Sesuai dengan hasil kuisioner online yang peneliti sebarkan, dan dari hasil uji statistik SPSS versi 25 , peneliti mendapatkan hasil yang sesuai dengan apa yang sedang diteliti. Bahwa ada hubungan antara $X_{3}$ dan $Y_{2}$ yaitu, informasi berita dengan kebutuhan diversi. Sesuai dengan teori yang sudah dijabarkan oleh peneliti pada bab sebelumnya. Yang mana informasi berita dapat mempengaruhi atau ada hubungannya dengan kebutuhan diversi pada mahasiswa Jurnalistik Fikom Unisba.

\section{Hubungan Antara Informasi dengan Kebutuhan Identitas Personal}

Tabel 9. Hasil Analisis Hubungan Informasi dengan

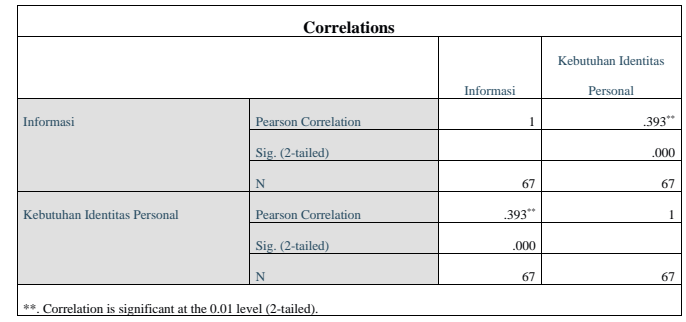

Berdasarkan uji korelasi yang telah dilakukan, diputuskan hasil bahwa kedua dimensi yang diujikan terdapat hubungan yang signifikan dengan nilai sig. (2-tailed) $<$ dari nilai $\alpha$, yaitu $(0.00<0.01)$ artinya H0 ditolak dan H1 yang berbunyi "Terdapat hubungan antara informasi pemberitaan penanggulangan covid-19 di Tempo.co dengan kebutuhan identitas personal pada mahasiswa Jurnalistik Fikom Unisba" diterima. Koefisien korelasi pun menunjukkan angka 0,393 yang berarti terdapat hubungan rendah tetapi pasti antara variabel $\left(\mathrm{X}_{3}\right)$ indikator informasi dengan variabel $\left(\mathrm{Y}_{3}\right)$ kebutuhan identitas personal. Nilai koefisien korelasi yang positif atau searah menandakan bahwa semakin besar aspek informasi pada pemberitaan penanggulangan covid-19 di Tempo.co semakin ditingkatkan akan berdampak baik pada kebutuhan identitas personal pada mahasiswa Jurnalistik Fikom Unisba.

Sesuai dengan hasil kuisioner online yang peneliti sebarkan, dan dari hasil uji statistik SPSS versi 25, peneliti mendapatkan hasil yang sesuai dengan apa yang sedang diteliti. Bahwa ada hubungan antara $\mathrm{X}_{3}$ dan $\mathrm{Y}_{3}$ yaitu, informasi berita dengan kebutuhan identitas personal. Sesuai dengan teori yang sudah dijabarkan oleh peneliti pada bab sebelumnya. Yang mana informasi berita dapat mempengaruhi atau ada hubungannya dengan kebutuhan identitas personal pada mahasiswa Jurnalistik Fikom Unisba.

\section{Kesimpulan}

Berdasarkan hasil analisis data yang telah disajikan pada bab sebelumnya, penulis mengambil beberapa kesimpulan. Melalui data hasil penelitian yang telah dikaji oleh penulis dapat ditarik kesimpulan bahwa, terdapat hubungan yang cukup berarti dan signifikan antara indikator nilai kebaharuan pada pemberitaan penanggulangan covid-19 di Tempo.co dengan kebutuhan kognitif pada mahasiswa Jurnalistik Fikom Unisba. Lalu terdapat hubungan yang rendah tetapi pasti dan signifikan antara indikator nilai kebaharuan pada pemberitaan penanggulangan covid19 di Tempo.co dengan kebutuhan diversi pada mahasiswa Jurnalistik Fikom Unisba. Lalu 
terdapat hubungan yang cukup berarti dan signifikan antara indikator nilai kebaharuan pada pemberitaan penanggulangan covid-19 di Tempo.co dengan kebutuhan identitas personal pada mahasiswa Jurnalistik Fikom Unisba. Kesimpulan yang kedua bahwa terdapat hubungan yang cukup berarti dan signifikan antara indikator nilai aktual pada pemberitaan penanggulangan covid-19 di Tempo.co dengan kebutuhan kognitif pada mahasiswa Jurnalistik Fikom Unisba. Lalu terdapat hubungan yang rendah tetapi pasti dan signifikan antara indikator nilai aktual pada pemberitaan penanggulangan covid-19 di Tempo.co dengan kebutuhan diversi pada mahasiswa Jurnalistik Fikom Unisba. Lalu terdapat hubungan yang cukup berarti dan signifikan antara indikator nilai aktual pada pemberitaan penanggulangan covid-19 di Tempo.co dengan kebutuhan identitas personal pada mahasiswa Jurnalistik Fikom Unisba. Kesimpulan yang ketiga bahwa, terdapat hubungan yang cukup berarti dan signifikan antara indikator nilai informasi pada pemberitaan penanggulangan covid-19 di Tempo.co dengan kebutuhan kognitif pada mahasiswa Jurnalistik Fikom Unisba. Lalu terdapat hubungan yang cukup berarti dan signifikan antara indikator nilai informasi pada pemberitaan penanggulangan covid-19 di Tempo.co dengan kebutuhan diversi pada mahasiswa Jurnalistik Fikom Unisba. Lalu terdapat hubungan yang rendah tetapi pasti dan signifikan antara indikator nilai informasi pada pemberitaan penanggulangan covid-19 di Tempo.co dengan kebutuhan identitas personal pada mahasiswa Jurnalistik Fikom Unisba.

\section{Acknowledge}

Penulis mengucapkan terima kasih kepada Pak Yadi Supriadi, S Sos., M Phill atas saran dan bimbingannya dalam penulisan jurnal ini dan juga kepada mahasiswa Jurnalistik Fikom Unisba yang telah bersedia menjadi responden pada penelitian ini.

\section{Daftar Pustaka}

[1] Bungin, Burhan. 2009. Metodologi Penelitian Kuantitatif. Jakarta: Kencana

[2] Darmawan, Deni. 2013. Metode Penelitian Kuantitatif. Bandung: PT Remaja Rosdakarya Offset

[3] Effendy, Onong Uchjana. 2003. Ilmu Teori dan Filsafat Komunikasi. Bandung: Remaja Rosda Karya

[4] Effendy, Onong Uchjana. 2004. Ilmu Komunikasi: Teori dan Praktek. Bandung: Remaja Rosda Karya

[5] Morissan. 2010. Teori Komunikasi Massa. Jakarta: Ghalia Indonesia

[6] McQuail, Denis. 2011. Teori Komunikasi Massa McQuail, Edisi 6 Buku 1. Jakarta: Salemba Humanika

[7] Nuruddin. 2014. Pengantar Komunikasi Massa. Jakarta: PT Raja Grafindo Persada

[8] Purba, Amir, dkk. 2016. Pengantar Ilmu Komunikasi. Medan: Pustaka Bangsa Press.

[9] Rakhmat, Jalaluddin. 2005. Psikologi Komunikasi. Bandung: Remaja Rosda Karya

[10] Rakhmat, Jalaluddin. 2017. Metode Penelitian Komunikasi. Bandung: Simbiosa Rekatama

[11] Santana K, Septiawan. 2017. Jurnalisme Kontemporer Edisi Kedua. Jakarta: Yayasan Obor Indonesia

[12] Sugiyono. 2012. Metode Penelitian Kuantitatif Kualitatif dan $R \&$ D. Bandung: Alfabeta

[13] Suryawari, Indah. 2014. Jurnalistik Suatu Pengantar Teori dan Praktik. Bogor: Ghalia Indonesia

[14] Haqqu, Rizca. 2020. Uji Uses and Gratifications Dalam Intensitas Menonton Program Talk Show Melalui Televisi. Program Studi Ilmu Komunikasi, Universitas Telkom

[15] Hutagaol, Sarah. 2015. Pengaruh Isi Pesan Tweet @Metro_TV Terhadap Pemenuhan Kebutuhan Informasi Mahasiswa Ilmu Komunikasi Untirta 2012-2014. FISIP Untirta Repository

[16] Manopo, Rivo. 2015. "Pengaruh Displin Kerja, Motivasi Kerjadan Pengembangan Karir Terhadap Kepuasan Kerja Pada Tvri Sulawesi Utara.” Jurnal EMBA Vol.3 No.3 September, (hlm.1220-1231) 
[17] Supriadi, Yadi, M. Subur Drajat, Nuril Lutfiah Saleh, Anisa Suci R, dan Audi Siti Nur Huda. 2020. "The Role of The West Java Indonesian Broadcasting Commission (KPID) in Preventing Citizen Panic Related to News and Information Regarding Covid-19". Mediator. Vol. 13, No. 2, Tahun 2020 (hlm. 167-177).

[18] Utomo, Dea Anggraeni. 2013. Motif Pengguna Jejaring Sosial Google+ Di Indonesia. Jurnal E-Komunikasi Vol I. No. 3 Tahun 2013

[19] Yuwono, Eric. 2013. Kepuasan Masyarakat Surabaya Dalam Menonton Program Variety Show "Dahsyat" Di RCTI. Jurnal E-Komunikasi Vol I. No.1 Tahun 2013

[20] Watie, E.D.S., (2011). Komunikasi dan Media Sosial. The Messenger Vol III 